\title{
US Compliance with WTO Rulings on Zeroing in Anti-Dumping
}

\author{
United States-Zeroing (EC); United States-Zeroing (Japan) \\ Article 21.5 DSU Implementation Reports \\ BERNARD HOEKMAN * \\ World Bank and CEPR \\ JASPER WAUTERS* *
}

\begin{abstract}
This paper reviews the WTO Appellate Body Reports on United States-Zeroing (EC) (Article 21.5 DSU - EC) (WT/DS294/AB/RW, 14 May 2009) and United States-Zeroing (Japan) (Article 21.5 DSU - Japan)

(WT/DS322/AB/RW, 18 August 2009). The Appellate Body found that the United States had not brought its anti-dumping measures into compliance with the WTO Anti-Dumping Agreement as it continued to use zeroing in annual reviews of anti-dumping orders. We argue that this conclusion - based on a complicated discussion of what constitutes a 'measure taken to comply' - could have been reached through a much simpler and direct argument. Continued noncompliance by the United States generates costs to traders targeting the United States and the trading system more generally. We argue that from a broader WTO compliance perspective consideration should be given to stronger multilateral surveillance of anti-dumping practice by all WTO members and to more analysis and effective communication by economists regarding the costs of zeroing and anti-dumping practices more generally.
\end{abstract}

\section{Introduction}

This paper reviews the WTO Appellate Body (AB) Reports on United StatesZeroing (EC) (Article 21.5 DSU - EC) (WT/DS294/AB/RW, 14 May 2009) ${ }^{1}$ and United States-Zeroing (Japan) (Article 21.5 DSU - Japan) (WT/DS322/AB/RW,

\footnotetext{
* Email: Bhoekman@worldbank.org

**Email: jaspermartijnwauters325@gmail.com
}

The paper is a contribution to The American Law Institute project on the case law of the WTO, led by Henrik Horn and Petros Mavroidis. We thank Marco Bronckers, Chad Bown, and Tom Prusa for helpful discussions and Henrik Horn, Rob Howse, Petros Mavroidis, and participants in the June 7, 2010 American Law Institute conference in Geneva for comments on the first draft. The views expressed are personal and should not be attributed to our employers.

1 Appellate Body Report, United States-Laws, Regulations and Methodology for Calculating Dumping Margins ('Zeroing') - Recourse to Article 21.5 of the DSU by the European Communities, WT/DS294/AB/RW and Corr.1, adopted 11 June 2009. 
18 August 2009). ${ }^{2}$ These disputes concerned the manner in which the United States implemented - or failed to implement - the WTO rulings relating to the prohibition of zeroing in anti-dumping investigations and reviews. The main legal issue dealt with in these compliance cases was what prospective implementation means in the context of a retrospective system of administering anti-dumping measures.

As the United States is the only country with such a system, the Reports are very specific to the US situation and are limited to the question of implementation in the context of anti-dumping measures. The Reports are nonetheless of interest in that they provide further insight into the approach taken by the $\mathrm{AB}$ in assessing compliance with WTO rulings. In the two Reports, the AB found that the United States was not in compliance, in that any action taken after the expiry of the 'reasonable period of time' (RPT) for implementation of previous AB Reports, whether a legal determination of the amount of duties due or the simple collection of duties, must be consistent with the WTO Anti-Dumping (AD) Agreement.

In what follows, we first summarize the disputes (Section 1), the Panel Reports (Section 2), and the appeals and the AB Reports (Section 3). In Section 4, we discuss the reasoning in the $\mathrm{AB}$ Reports. We argue that the Appellate Body conclusion could have been reached in a much more direct way rather than after a lengthy and unnecessarily complicated discussion of what constitutes a 'measure taken to comply'. Given extensive prior analysis of the technical aspects of zeroing, in Section 5 we focus on the available evidence on the economic impact of (continued) US zeroing. As the practice potentially affects all exporters to the United States, we argue that the chilling effect of continued use of zeroing may be nontrivial. Moreover, continued use of zeroing can be expected to lead to both WTO-legal retaliation in the future by affected WTO members and, potentially more important, emulation by other countries. As anti-dumping is increasingly used by developing countries, we argue that from a broader WTO compliance perspective consideration should be given to strengthening multilateral surveillance of anti-dumping practice around the world to make the effects of zeroing and other methodologies on anti-dumping margins more transparent. Section 6 concludes.

\section{The dispute}

This dispute concerns the manner in which the United States implemented a number of rulings by the WTO in respect of the use of zeroing in anti-dumping investigations and reviews. In the context of the dispute known as US-Zeroing $(E C)$, the European Union (the 'EU') challenged the use of zeroing both as such, and as applied by the United States in the specific context of a large number of original investigations and reviews relating to different products from the EU. The

2 Appellate Body Report, United States - Measures Relating to Zeroing and Sunset Reviews -Recourse to Article 21.5 of the DSU by Japan, WT/DS322/AB/RW, adopted 31 August 2009. 
dispute known as US-Zeroing (Japan) concerned a similar challenge by Japan of the use of zeroing as such, and as applied by the United States in the context of a number of original investigations and reviews relating to a number of steel-related products such as ball bearings from Japan.

The question of zeroing has been at the heart of many Panel and Appellate Body Reports. It essentially relates to the way in which dumping margins are calculated in the context of anti-dumping measures. In order to determine whether a product has been dumped, the export price of the product will be compared to its normal value, which is the comparable price for which the like product is sold in the ordinary course of trade on its domestic market. This comparison will normally involve a large amount of transactions. When 'zeroing', an investigating authority will not allow transactions in which the export price was actually equal to or higher than the normal value (no dumping) to offset the transactions in which the export price was below the normal value (dumping). In other words, if there are 100 transactions, 50 of which are dumped because the export price is $10 \%$ lower than the normal value and 50 of which are not dumped because the export price is $20 \%$ higher than the normal value, dumping will be found to exist, even though, on average, the margin of dumping was below zero. The margin of dumping will be determined on the basis of the first 50 transactions, as a 'zero' margin will be assigned to the latter 50 transactions, even though their margin was actually negative $(-20 \%)$. As negative margins cannot be used to offset positive margins, a finding of dumping is more likely and the amount of the margin of dumping will be inflated.

The Panel in its Report on US-Zeroing (EC) found that the United States had acted inconsistently with Article 2.4.2 AD Agreement as regards the 15 original investigations at issue. The Panel considered that this was so because 'USDOC [US Department of Commerce] did not include in the numerator used to calculate weighted average dumping margins any amounts by which average export prices in individual averaging groups exceeded the average normal value for such groups'. ${ }^{3}$ The Panel also found that, in the context of original investigations, the zeroing methodology as such, and thus independent of any specific application, was inconsistent with Article 2.4.2 AD Agreement. ${ }^{4}$ However, the Panel considered that zeroing was permissible in the context of administrative reviews. The $\mathrm{AB}$ reversed the Panel on this and held that by using zeroing in the administrative reviews, the USDOC had violated Article 9.3 AD Agreement and Article VI:2 GATT.

3 Panel Report, United States-Laws, Regulations and Methodology for Calculating Dumping Margins ('Zeroing'), WT/DS294/R, adopted 9 May 2006, as modified by Appellate Body Report, WT/DS294/AB/R, DSR 2006:II, 521 (US-Zeroing (EC)), para. 7.32. Furthermore, having adjudicated the claims of the EC under Article 2.4.2 AD Agreement, the Panel considered it unnecessary to rule on its claims under Article 2.4 AD Agreement.

4 Panel Report, US-Zeroing (EC), para. 7.106. 
Similar issues arose in the US-Zeroing (Japan) case, where the Panel found that the use of zeroing in the context of weighted-average-to-weighted-average comparisons ('model zeroing') by the USDOC in the context of original investigations is 'as such' inconsistent with Article 2.4.2 AD Agreement because the dumping margin so calculated does not take into account all comparisons between the normal value and the export price. The Panel also held that by applying model zeroing in the anti-dumping investigation of imports of certain cut-to-length carbon-quality steel products from Japan, the United States had infringed Article 2.4.2 AD Agreement. This aspect of the Panel's findings was uncontroversial.

In respect of zeroing in the context of transaction-to-transaction comparisons ('simple zeroing'), the Panel considered that this could be permissible and was overturned on appeal. The $\mathrm{AB}$ found that zeroing while using the transactionto-transaction comparison method in original investigations is inconsistent with Article 2.4.2 AD Agreement:

In the light of our analysis of Article 2.4.2 of the Anti-Dumping Agreement, we conclude that, in establishing 'margins of dumping' under the T-T comparison methodology, an investigating authority must aggregate the results of all the transaction-specific comparisons and cannot disregard the results of comparisons in which export prices are above normal value. ${ }^{5}$

Therefore, it held that the USDOC violated Article 2.4.2 AD Agreement by using zeroing in the transaction-to-transaction comparison method in original investigations. ${ }^{6}$

The AB reversed the Panel's findings in respect of the permissibility of zeroing in the context of reviews, ruling that zeroing is not permitted in the context of any type of review. In particular, the $\mathrm{AB}$ found that the United States had violated Articles 9.3 and 9.5 AD Agreement and Article VI:2 GATT by maintaining simple zeroing in administrative reviews (also known as 'periodic reviews') and newshipper reviews. ${ }^{7}$ The $\mathrm{AB}$ also held that zeroing in administrative and new-shipper reviews is inconsistent with the fair-comparison requirement of Article 2.4 AD Agreement. As a result, it held that the United States had acted in contravention of its WTO obligations by applying simple zeroing in the 11 administrative reviews in

5 Appellate Body Report, United States-Measures Relating to Zeroing and Sunset Reviews, WT/DS322/AB/R, adopted 23 January 2007, DSR 2007:I, 3 (US-Zeroing (Japan)), para. 137.

6 The Appellate Body also found that this method of dumping-margin calculation is not unbiased or even-handed and accordingly zeroing in transaction-to-transaction comparisons violates the faircomparison requirement. Consequentially, the Appellate Body reversed the Panel's decision in this regard and held that the United States infringed Article 2.4 AD Agreement by maintaining simple zeroing in original investigations.

7 The Appellate Body considered that dumping and dumping margins can only exist at the level of a product and that this equally prohibits zeroing in administrative reviews as the dumping margin acts as a ceiling for the total amount of anti-dumping duties that can be collected in any type of duty-assessment system. 
question. Finally, the $\mathrm{AB}$ reversed the Panel in respect of the use of zeroing in sunset reviews, concluding that the presence of the terms 'review' and 'determine' in Article 11.3 AD Agreement require a reasoned conclusion based on positive evidence and a sufficient factual basis. If, in sunset reviews, the authorities relied on historical dumping margins, these margins should be in conformity with Article 2.4 AD Agreement. Hence, the $\mathrm{AB}$ held that by relying in sunset reviews on the dumping margins calculated in the administrative reviews using zeroing, the United States had infringed Article 11.3 AD Agreement.

The RPT for the United States to implement the recommendations and rulings of the Dispute Settlement Body (DSB) in the case of US-Zeroing (EC) was set, by agreement of the parties, at 11 months, expiring on 9 April 2007. ${ }^{8}$ On 13 September 2007, the EU requested the establishment of a Panel pursuant to Article 21.5 of the Dispute Settlement Understanding (DSU), ${ }^{9}$ which applies ' when there is disagreement as to the existence of consistency with a covered agreement of measures taken to comply with the recommendations and rulings' of the DSB. In the context of the US-Zeroing (Japan) dispute, the RPT for the United States to bring its measures into conformity expired on 24 December $2007 .{ }^{10}$ On 7 April 2008, Japan requested the establishment of a Panel ${ }^{11}$ pursuant to Article 21.5 of the DSU.

\section{Complainant arguments and the US defense}

The United States was required to implement the rulings of the DSB in the disputes on US-Zeroing (EC) and US-Zeroing (Japan) relating to the zeroing methodology 'as such' both in the context of original investigations (US-Zeroing (EC)) and in the context of administrative reviews and new-shipper reviews (US-Zeroing (Japan)). It was also required to correct the use of zeroing 'as applied' in a number of original investigations, as well as administrative reviews and sunset reviews. We briefly discuss the arguments of the parties in respect of each case.

\section{US-Zeroing $(E C)$}

The EU's challenge related first of all to the measures expressly identified by the United States as 'measures taken to comply' with the DSB rulings. The EU thus challenged the Section 129 determinations adopted by the United States to implement the recommendations and rulings of the DSB. The EU argued that one such determination was vitiated by a calculation error. Of a number of other determinations, the EU argued that they were inconsistent with the United States's 
obligations under the AD Agreement since no new injury analysis was performed, even though the recalculation of the dumping margins without zeroing led to the exclusion of a number of exporters previously found to be dumping. The EU also challenged the US determination of the all-others rate based on margins that were below de minimis or based on facts available. These sets of claims could be qualified as 'ordinary' implementation issues as they relate to the measures taken to comply with a DSB ruling and examine their consistency under the relevant Agreement. These claims are unrelated to the question of zeroing as it is undisputed that, in these redeterminations, the United States indeed no longer used 'zeroing'.

In addition, the EU challenged a number of reviews that were undertaken by the United States as part of the normal ongoing life of the anti-dumping orders originally challenged by the EU. The EU thus claimed violations in respect of subsequent administrative reviews, changed-circumstances reviews, and sunset reviews adopted in relation to the 15 original investigations and the 16 administrative reviews at issue in the original proceedings, as well as liquidation and assessment instructions and final liquidation of duties resulting from those subsequent reviews. The EU argued that all of these subsequent reviews undertaken in the context of $\mathrm{AD}$ orders of which the original determination or the administrative review were found to be WTO-inconsistent, were sufficiently related to the challenged measures to be considered as 'measures taken to comply'. Since the United States continued to use zeroing in these subsequent reviews, the EU argued that the United States continued to violate the AD Agreement. Similarly, the EU argued that any liquidation instructions based on a determination vitiated by zeroing that were made after the expiry of the RPT were WTO-inconsistent actions. Finally, the EU argued that the United States, by omission, had failed to implement the DSB's rulings. In particular, the EU noted that there was a gap between the end of the RPT for implementation and the adoption of some of the Section 129 determinations through which the United States sought to implement the WTO rulings.

The United States considered it had fully implemented the DSB rulings by amending, through several so-called 'Section 129 determinations', the challenged original determinations ${ }^{12}$ and reviews ${ }^{13}$ and by making an effective end to the use of

12 On 9 April 2007, the USDOC issued Section 129 determinations in which it recalculated, without zeroing, the margins of dumping for 11 of the original investigations at issue in the original proceedings. The results of those Section 129 determinations became effective two weeks later, on 23 April 2007. The Section 129 determination in the remaining case was issued on 20 August 2007, effective 31 August 2007.

13 With respect to the 16 administrative reviews at issue in the original proceedings, the United States considered that the cash-deposit rates calculated in those proceedings - with the exception of one exporter - were no longer in effect because they had been superseded by subsequent administrative reviews. Consequently, 'no further action was taken by the United States in order to implement the DSB recommendations and rulings in respect of these administrative review[s]'. 
model zeroing in original investigations. ${ }^{14}$ According to the United States, only these Section 129 determinations are 'measures taken to comply' in respect of which the Panel has a mandate under article 21.5 of the DSU. The United States acknowledged that the USDOC issued, in the ordinary course, administrativereview determinations with respect to anti-dumping duty orders relating to the original investigations at issue in the original proceedings. The USDOC continued to apply zeroing when calculating margins of dumping in those administrative reviews. ${ }^{15}$ It also acknowledged that sunset reviews were conducted with respect to some of the measures at issue in the original proceedings. Twelve sunset-review determinations of these measures resulted in the continuation of the relevant AD duty order. ${ }^{16}$ According to the United States, these subsequent reviews should not be considered as 'measures taken to comply' with the DSB rulings.

\section{US-Zeroing (Japan)}

Japan considered that the United States had failed to comply with the recommendations and rulings of the DSB. It argued that the United States had done nothing to implement the DSB rulings in respect of the 'as such' claims relating to the zeroing methodology in the context of transaction-to-transaction comparisons in original investigations, and under any comparison methodology in periodic and new-shipper reviews. It further alleged that the United States had not amended the importer-specific assessment rates in the context of five periodic reviews that were found to be WTO-inconsistent in the original proceedings. In addition, Japan considered that the United States committed the same zeroing violation in the case of four subsequent periodic reviews, one of which was only adopted in the course of the Panel's proceedings, which Japan considered to be 'measures taken to comply'. Japan also argued that the United States failed to bring into compliance the sunset-review determination of 4 November 1999, which was found to be vitiated by the use of zeroing. Finally, Japan argued that by continuing with certain liquidation actions relating to reviews that were completed before the end of the RPT, but where such actions were taken after the expiry of the RPT, the United States acted in violation of Articles II:1(a) and II:1(b) of the GATT 1994.

The United States argued it had brought its measures into compliance. It asserted that the zeroing procedures challenged 'as such' by Japan in the original proceeding no longer exist, as on 27 December 2006 USDOC published a final

14 On 27 December 2006, the United States announced that it would terminate the use of 'model zeroing' in original investigations in which the margins of dumping are determined on the basis of weighted-average-to-weighted-average comparisons of export prices and normal value. This modification became effective on 22 February 2007.

15 See Panel Report, United States - Laws, Regulations and Methodology for Calculating Dumping Margins ('Zeroing') - Recourse to Article 21.5 of the DSU by the European Communities, WT/DS294/ RW, adopted 11 June 2009, as modified by Appellate Body Report WT/DS294/AB/RW (Panel Report, US-Zeroing (EC) Article 21.5 DSU) para. 3.1(c).

16 Panel Report, US-Zeroing (EC) (Article 21.5 DSU), para. 3.1(e). 
notice announcing that it would no longer apply zeroing in weighted-average-toweighted-average comparisons in original investigations. ${ }^{17}$ It also held that it complied regarding certain of the challenged administrative reviews by withdrawing the WTO-inconsistent cash-deposit rates with prospective effect, replacing them with new cash-deposit rates determined in subsequent administrative reviews. The United States denied it was required to take any compliance action in respect of the importer-specific assessment rates determined in several administrative reviews. In addition, it asserted that a number of reviews challenged by Japan that were not challenged in the original proceedings should not be considered as 'measures taken to comply' within the meaning of Article 21.5 of the DSU, and therefore fell outside the scope of these proceedings. It also argued that a review which was not terminated at the time Japan requested the establishment of the implementation Panel was not within the Panel's terms of reference. Finally, the United States asserted that it was not required to take any action to comply with the DSB's recommendations and rulings regarding the 4 November 1999 sunset review, because the relevant likelihood of dumping determination continues to be based on a number of dumping rates not called into question by the findings of the Appellate Body. ${ }^{18}$

\section{The Panel Report}

We next briefly discuss the main elements of the Panel's ruling in both cases.

\section{US-Zeroing (EC)}

In its Report on US-Zeroing (EC), the Panel upheld some, but not all of the EU's claims. As to what actions are to be considered as 'measures taken to comply', the Panel noted that 'a nexus-based analysis, as articulated in Australia-Leather II (Article 21.5 - US), Australia-Salmon (Article 21.5 - Canada), and US-Softwood Lumber (Article 21.5 - Canada) is useful in examining which measures challenged by a complainant properly fall within the scope of an Article 21.5 proceeding'. It thus found that if the 'contested measures are closely connected with the measures at issue in the original dispute or with the steps taken by the Member to implement the DSB's recommendations and ruling', they are measures taken to comply. ${ }^{19}$

The Panel examined the links, 'in terms of their nature and of their effects', that exist in general between the subsequent reviews challenged by the European Communities and the measures at issue in the original dispute and the

17 'Antidumping Proceedings: Calculation of the Weighted Average Dumping Margin During an Antidumping Investigation', Final Modification, 71 Fed. Reg. 77722, 77723 (USDOC, 27 December 2006).

18 Panel Report, United States - Measures Relating to Zeroing and Sunset Reviews - Recourse to Article 21.5 of the DSU by Japan, WT/DS322/RW, adopted 31 August 2009, upheld by Appellate Body Report WT/DS322/AB/RW, paras. 3.2-3.5.

19 Panel Report, US-Zeroing (EC) (Article 21.5 DSU), paras. 8.97-8.98. 
recommendations and rulings of the DSB. It found that 'successive determinations of different types are made in the context of a single trade remedy proceeding, involving the imposition and assessment of anti-dumping duties on imports of a particular subject product, from the same country. They all concern the imposition and collection of anti-dumping duties under a particular anti-dumping order. In this sense, these determinations form part of a continuum of events and measures that are all inextricably linked. ${ }^{20}$ It then considered the links, 'in terms of the timing of the determinations at issue' and found that 'only those subsequent reviews that were decided after such [DSB] adoption could be taken into consideration as part of a compliance panel's examination of the implementation of DSB recommendations and rulings' ${ }^{21}$ In other words, the Panel was of the view that only 'measures adopted following the adoption of the DSB's recommendations may have a close link with the DSB's recommendations and rulings and with the steps, if any, taken by the implementing Member to achieve compliance with the recommendations and rulings, and therefore warrant inclusion in the scope of an Article 21.5 proceeding'. ${ }^{22}$ This is so, according to the Panel, because 'the application of a nexus-based test should primarily aim at bringing within the scope of the compliance dispute measures that potentially circumvent implementation or undermine measures officially taken to comply'. Therefore, 'none of the subsequent reviews challenged by the European Communities that were decided before the adoption of the DSB's recommendations and rulings fall within our terms of reference'. ${ }^{23}$

Having established the measures that fell within its terms of reference, the Panel examined the relevant claims of the EU in respect of such measures. It agreed with the EU that the United States had violated its WTO obligations by making determinations of the final amount of duty assessment after the end of the RPT in certain administrative reviews, and by continuing to apply cash-deposit rates to certain imports established in an administrative review that was found to be WTO-inconsistent. Liquidation of anti-dumping duties calculated with zeroing pursuant to final duty-assessment determinations made before the end of the RPT was deemed not to be WTO-inconsistent. In essence, the Panel was of the view that any final determination in a related periodic review made after the end of the RPT must comply with the WTO prohibition on zeroing, even when it relates to imports that entered the country before the end of the RPT. However, according to the Panel, when the final determination using zeroing is made before the end of the RPT and thus at a point in time that the United States's violation was not subject to a sanction, it is irrelevant that the execution of that determination through liquidation instructions takes place after the end of the RPT. According to the Panel,

20 Ibid., para. 8.103.

21 Ibid., para. 8.100; para. 8.115.

22 Ibid., para. 8.116 .

23 Ibid., para. 8.119. 
'the relevant date for implementation of DSB recommendations and rulings concerning anti-dumping duties by a Member operating a retrospective duty assessment system is the date of the final determination of liability'. ${ }^{24}$

The Panel further found that the United States had violated Article 3 of the AD Agreement by maintaining the AD duty orders, in certain cases, without having made a new determination of injury and of the volume of dumped imports even though the redeterminations without zeroing led to the exclusion of a number of exporters that were no longer considered to have been dumped. However, the Panel found that the United States did not act inconsistently with Article 9.4 of the AD Agreement in the establishment of 'all others' rates in the Section 129 determinations in the relevant cases since it was of the view that Article 9.4 does not impose any obligations on authorities when all margins are either de minimis, zero, or based on facts available. The Panel did not make findings for technical reasons on a number of other claims.

\section{US-Zeroing (Japan)}

The Panel upheld almost all of the arguments of Japan. It found that the United States had failed to comply with the DSB's recommendations and rulings regarding the importer-specific assessment rates determined in a number of administrative reviews in respect of imports that were liquidated after the expiry of the RPT. It concluded that the United States was thus in continued violation of its obligations under Articles 2.4 and 9.3 of the AD Agreement and Article VI:2 of the GATT 1994. It also found that the United States acted inconsistently with Articles 2.4 and 9.3 of the AD Agreement and Article VI:2 of the GATT 1994 by applying zeroing in the context of those administrative reviews that were not challenged in the original dispute but which could be considered as measures taken to comply with the DSB rulings and recommendations because of their close nexus with the determinations challenged in the original proceedings.

In addition, the Panel held that the United States failed to comply with the recommendations and rulings of the DSB regarding the maintenance of zeroing procedures challenged 'as such' in the original proceedings. It found that the United States had not implemented the recommendations and rulings in the context of transaction-to-transaction comparisons in original investigations and under any comparison methodology in periodic and new-shipper reviews. It thus found that the United States remained in violation of Articles 2.4, 2.4.2, 9.3, and 9.5 of the AD Agreement and Article VI:2 of the GATT 1994. It also found that the United States was in violation of Articles II:1(a) and II:1(b) of the GATT 1994 with respect to certain liquidation actions taken after the expiry of the RPT, even

24 Ibid., para. 8.174. The Panel made no findings with respect to the EU claim that the United States violated the DSU by failing to take any measure to comply in respect of certain determinations found to be WTO inconsistent until well after the end of the RPT but before the start of the implementation proceedings. 
when they were based on reviews terminated prior to the end of the RPT. The Panel thus adopted a different approach from that of the Panel on US-Zeroing $(E C) .{ }^{25}$ Finally, the Panel found that the United States had not complied with the DSB recommendations and rulings with respect to the 1999 sunset review. ${ }^{26}$

\section{The appeal and the Appellate Body Reports}

We next outline the major arguments raised on appeal and summarize the findings of the $\mathrm{AB}$ in respect of the most relevant matters in both cases.

\section{US-Zeroing (EC)}

A number of issues were raised on appeal. ${ }^{27}$ Most importantly, the EU argued the Panel erred in finding that subsequent reviews that predated the adoption of the recommendations and rulings of the DSB did not fall within its terms of reference, because they did not have a sufficiently 'close nexus' with the original measures at issue and the recommendations and rulings of the DSB. The EU also considered that the Panel erred by not extending the US compliance obligations to actions consequent to the assessment of duties, including the collection or liquidation of duties occurring after the end of the RPT when they related to administrativereview determinations completed before that date.

In addition, the EU challenged a number of other aspects of the Panel's findings, such as the Panel's refusal to make a finding in respect of measures taken to comply after the end of the RPT but before the request for establishment of an implementation Panel was submitted by the EU. The EU also challenged the Panel's refusal to examine an alleged calculation error in a measure taken to comply for reason of the fact that this error could have been challenged in the original dispute as it had also been present in the original measure. It also contested the Panel's findings in respect of the lack of disciplines in respect of the 'all others' rates when all margins are determined based on zeroing or are de minimis.

The United States challenged a number of the Panel's findings, most importantly the 'close nexus' test developed by the Panel that formed the basis for the inclusion of a significant number of reviews that had not been challenged in the original dispute since they postdated the original request for establishment.

\section{The Appellate Body Report}

The Appellate Body sided with the EU on an important number of claims overturning the Panel's findings. Our discussion in what follows focuses mainly on the

25 The Panel expressly recognized this difference in approach. Panel Report, US-Zeroing (Japan) (Article 21.5 DSU), para. 7.208 and footnote 220.

26 Ibid., para. 8.1.

27 On 13 February 2009, the EU notified the DSB of its intention to appeal certain issues of law and legal interpretations developed in the Panel Report and filed a Notice of Appeal (WT/DS294/28). On 25 February 2009, the United States notified the DSB of its intention to appeal certain issues of law and legal interpretations developed in the Panel Report and filed a Notice of Other Appeal (WT/DS294/29). 
scope of the term 'measures taken to comply' in the specific context of US antidumping proceedings. We also briefly discuss the manner in which the AB dealt with a number of other issues on appeal, i.e. sunset reviews, the implementation gap between the end of the RPT and actual compliance, the challenge of aspects of a measure that were part of the original measure and were not challenged at the time of the original dispute, and the limits imposed by the AD Agreement in respect of the 'all others' rate under Article 9.4 AD Agreement.

\section{1. 'Measures taken to comply' and 'subsequent reviews'}

The EU argued that the Panel erred, inter alia, in finding that the subsequent reviews that predated the adoption of the recommendations and rulings of the DSB did not fall within its terms of reference because they did not have a sufficiently close nexus with the original measures at issue and the recommendations and rulings of the DSB.

The AB first clarified that it considered 'that successive administrative, changed circumstances, and sunset review determinations issued in connection with the measures at issue in the original proceedings constitute separate and distinct measures, which therefore cannot be properly characterized as mere "amendments" to those measures', ${ }^{28}$ thus rejecting the EU's argument that any subsequent reviews were, in any case, mere amendments of the challenged measures and for that reason alone properly before the Panel. ${ }^{29}$ The AB recalled that it had previously 'expressed the view that a panel's mandate under Article 21.5 of the DSU is not necessarily limited to measures that the implementing Member maintains are taken "in the direction of" or "for the purpose of achieving" compliance with the recommendations and rulings of the DSB. ${ }^{{ }^{30}}$ It reiterated its view that "measures with a "particularly close relationship" with the declared measure "taken to comply", and to the recommendations and rulings of the DSB, may also fall within the purview of a compliance panel', ${ }^{31}$ and that 'a panel's determination of whether such a "close relationship" exists will depend upon the particular factual and legal background, and may call for an examination of the timing, nature, and effects of the various measures before the panel'. ${ }^{32}$

28 Appellate Body Report, US-Zeroing (EC) (Article 21.5 DSU), para. 192.

29 The Appellate Body recalled that, in a previous case, it had already found that subsequent reviews are 'connected stages under the same anti-dumping duty order', and that it had also made clear before that subsequent reviews involve 'successive determinations' and thus do not constitute 'mere "amendments" to the immediately preceding measure, because they constitute distinct determinations'. Appellate Body Report, US-Zeroing (EC) (Article 21.5 DSU), para. 192.

30 Appellate Body Report, US-Zeroing (EC) (Article 21.5 DSU), para. 202.

31 Ibid., para. 204.

32 Ibid., para. 204. 
The $\mathrm{AB}$ then explained why it agreed with the nexus test as developed by the Panel but disagreed as to the impact of the factor time when applying this test:

At the outset, we agree with the Panel that measures taken to comply with recommendations and rulings of the DSB ordinarily post-date the adoption of the recommendations and rulings. As the Appellate Body noted in US-Softwood Lumber IV (Article 21.5 - Canada), '[a]s a whole, Article 21 deals with events subsequent to the DSB's adoption of recommendations and rulings in a particular dispute'.

However, the Panel's finding that 'a measure taken before the adoption of the DSB's recommendations and rulings could rarely, if ever, be found to be a measure taken "to comply" with such recommendations and rulings' seems premised on the notion that a panel's mandate under Article 21.5 is limited to those measures taken 'in the direction of' or 'for the purposes of achieving' compliance with the recommendations and rulings of the DSB. As we have noted earlier, in the Appellate Body's interpretation, '[ $t$ ] he fact that Article 21.5 mandates a panel to assess "existence" and "consistency" tends to weigh against an interpretation of Article 21.5 that would confine the scope of a panel's jurisdiction to measures that move in the direction of, or have the objective of achieving, compliance.' For this reason, measures with a 'particularly close relationship' with the declared measures 'taken to comply', and to the recommendations and rulings of the DSB, may also fall within the scope of a panel proceeding under Article 21.5 of the DSU, even though such measures are not, strictly speaking, measures taken with the purpose of achieving compliance with those recommendations and rulings.

In this respect, we agree with the European Communities and the United States that the timing of a measure cannot be determinative of whether it bears a sufficiently close nexus with a Member's implementation of the recommendations and rulings of the DSB so as to fall within the scope of an Article 21.5 proceeding. Since compliance with the recommendations and rulings of DSB can be achieved before the recommendations and rulings of the DSB are adopted, a compliance panel may have to review events pre-dating the adoption of those recommendations and rulings in order to resolve a disagreement as to the 'existence' or 'consistency with a covered agreement' of such measures. Indeed, the United States argued before the Panel that it did not have to take further action to implement the recommendations and rulings of the DSB in respect of the administrative reviews at issue in the original proceedings, because they were superseded by subsequent administrative reviews that pre-dated the adoption of the DSB's recommendations and rulings. We also note the United States' argument that, where a measure is withdrawn prior to the DSB's recommendations and rulings, a Member may not need to take any further measures to comply with those recommendations and rulings after they are adopted. We do not see why a compliance panel should be unable to take such prior withdrawal into account. (footnotes omitted) ${ }^{33}$ 
In sum, the $\mathrm{AB}$ reversed the Panel's finding that reviews that predated the adoption of the Panel and AB Reports by the DSB could not be considered as 'measures taken to comply':

In our view, the Panel's formalistic reliance on the date of issuance of the subsequent reviews in ascertaining whether these reviews had a close nexus with the recommendations and rulings of the DSB was in error. The relevant inquiry was not whether the subsequent reviews were taken with the intention to comply with the recommendations and rulings of the DSB; rather, in our view, the relevant inquiry was whether the subsequent reviews, despite the fact that they were issued before the adoption of the recommendations and rulings of the DSB, still bore a sufficiently close nexus, in terms of nature, effects, and timing, with those recommendations and rulings, and with the declared measures 'taken to comply', so as to fall within the scope of Article 21.5 proceedings. $^{34}$

Applying the nexus test to the reviews challenged, the $\mathrm{AB}$ concluded that 'the use of zeroing in the excluded subsequent reviews provides the necessary link, in terms of nature or subject matter, between such measures, the declared measures "taken to comply", and the recommendations and rulings of the DSB'. ${ }^{35}$ In terms of effects, the $\mathrm{AB}$ found that 'to the extent that these administrative reviews generated assessment rates and cash deposit rates calculated with zeroing that replaced those found to be WTO-inconsistent in the original proceedings with the effects of assessment rates and cash deposit rates that continued to reflect the zeroing methodology, this would provide a sufficient link, in terms of effects, between those administrative reviews and the recommendations and rulings of the DSB, insofar as the requirement to cease using the zeroing methodology is concerned'. ${ }^{36}$

However, the $\mathrm{AB}$ added that the situation was different in respect of those administrative reviews that related to determinations for which section 129 redeterminations without zeroing had been made:

With respect to the 15 original investigations subject to the recommendations and rulings of the DSB, the United States issued Section 129 determinations in which it recalculated margins of dumping without zeroing that served as the basis for the going-forward cash deposit rates for the relevant anti-dumping duty orders. This recalculation without zeroing replaced the effects of the cash deposits calculated with zeroing in previous administrative reviews with the effects of cash deposits calculated without zeroing. Consequently, to the extent that the effects of the administrative and sunset reviews excluded from the Panel's terms of reference were replaced with those of a subsequent Section 129 determination in which zeroing was not applied, those subsequent reviews would generally not have the necessary link, in terms of effects, with the declared

34 Ibid., para. 226.

35 Ibid., para. 230.

36 Ibid., para. 231. 
measures 'taken to comply', and with the recommendations and rulings of the DSB, so as to fall within the Panel's terms of reference. ${ }^{37}$

Finally, the AB confirmed its view on the lack of significance of the factor 'time'. It concluded that 'the fact that the likelihood-of-dumping determinations in the sunset reviews listed above pre-date the adoption of the recommendations and rulings of the DSB is not sufficient to sever the pervasive links that we have found to exist, in terms of nature and effects, between such sunset reviews, the recommendations and rulings of the DSB, and the declared measures "taken to comply", ${ }^{38}$

The AB logically rejected the US cross-appeal on the Panel's nexus test, stressing the risk involved in adopting the US approach to implementation, arguing that:

the use of zeroing in subsequent determinations could undermine implementation in respect of original investigations. Although the Appellate Body noted in US - Softwood Lumber IV (Article 21.5 - Canada) that there are some limits on the scope of compliance proceedings, 'these limits should not allow circumvention by Members by allowing them to comply through one measure, while, at the same time, negating compliance through another. ${ }^{39}$

The use of zeroing to calculate assessment rates in administrative reviews issued after the end of the reasonable period of time is an indication that these reviews could undermine the compliance allegedly achieved by the United States. Indeed, the Section 129 determinations do not apply to entries prior to the end of the reasonable period of time and thus do not relate to compliance with respect to administrative reviews issued after the end of the reasonable period covering imports occurring before that date. ${ }^{40}$

The $\mathrm{AB}$ also rejected the US allegation that zeroing in a weighted-averageto-weighted-average context is not the same as zeroing in the context of a transaction-to-transaction comparison and that, for that reason, there is "no nexus' between the challenged measures and some of the reviews in which a different methodology was used. The argument concerning the risk of undermining the objective of effective compliance led one member of the $\mathrm{AB}$ to issue a separate opinion in which this member pointed to the lack of risk of circumvention in respect of two reviews in which no going-forward cash-deposit rates were set. ${ }^{41}$

37 Ibid., para. 232.

38 Ibid., para. 234.

39 Appellate Body Report, US - Softwood Lumber IV (Article 21.5 - Canada), para. 71; Appellate Body Report, US-Zeroing (EC) (Article 21.5 DSU), para. 250.

40 Appellate Body Report, US-Zeroing (EC) (Article 21.5 DSU), para. 252.

41 Ibid., paras. 267-268. According to this member, 'to the extent that the Section 129 determinations led to the revocation of the underlying anti-dumping duty orders, the 2004-2005 administrative reviews in Cases 1 and 6 had no bearing on the cash deposit rates that they would have otherwise "updated" or "superseded" in those Cases. Rather, the results of the 2004-2005 administrative reviews merely had a retrospective effect, which was the establishment of final anti-dumping duty liability for importers on entries taking place long before the end of the reasonable period of time.' 
This member thus warned against the overly broad reading of the term 'measures taken to comply'.42

Turning to the Panel's findings in respect of the timing of measures taken to comply, the AB agreed with the Panel in rejecting the US argument that the date of importation was the relevant date and that measures taken after the end of the RPT, even if they related to imports that entered prior to the end of the RPT should be 'zeroing-free'. However, the Panel also considered that a failure to comply could not be found with respect to actions occurring after the expiry of the RPT, such as assessment instructions by the USDOC to Customs, liquidation instructions by Customs to local port authorities, or actions to collect or liquidate duties, to the extent that these actions resulted from administrative reviews concluded before the end of the RPT. The AB rejected this approach and considered that any action taken after the end of the RPT, whether the determination of the amount of duties due or the actual liquidation of the entries after the end of the RPT should be consistent with the WTO Agreement:

Given the scope of the recommendations and rulings of the DSB, in order to achieve compliance, the United States had to cease using zeroing in the assessment of duties with respect to Cases 16 through 31 by the end of the reasonable period of time. Having said that, we consider that these compliance obligations are not limited to the cessation of zeroing in the calculation of assessment rates; rather, by implication, these obligations also extend to connected and consequent measures that are simply 'mechanically' derived from the results of an assessment review and applied in the ordinary course of the imposition of anti-dumping duties. ${ }^{43}$

The $\mathrm{AB}$ rejected the allegation that this approach would imply a retroactive implementation, which goes against the prospective nature of WTO implementation.

We observe, first, that an administrative review determination issued after the end of the reasonable period of time in which duty liability has been assessed for entries that occurred before that date also has an impact on entries taking place after the end of the reasonable period of time, because this determination sets going-forward cash deposit rates that apply to future entries. Under the United States' approach, prospective implementation would imply that cash deposit rates on entries after the end of the reasonable period of time do not reflect zeroing. Moreover, because compliance with the recommendations and rulings of the DSB implies cessation of zeroing in the assessment of final duty liability, and in the measures that, in the ordinary course of the imposition of antidumping duties, derive mechanically from the assessment of duties, whether the implementation is prospective or retroactive should not be determined by reference to the date when liability arises, but rather by reference to the time when

42 Ibid., para. 262.

43 Ibid., para. 306. 
final dumping duty liabilities are assessed or when measures that result mechanically from the assessment of duties occur. We consider that the obligation to cease using zeroing in the assessment of anti-dumping duty liability at the latest as of the end of the reasonable period of time 'is eminently prospective in nature'. ${ }^{44}$

The AB thus reversed the Panel's interpretation that the United States's obligation to implement the recommendations and rulings of the DSB does not extend to the actual collection and liquidation of duties, and to the issuance of assessment or liquidation instructions, when these actions result from administrative-review determinations made before the end of the RPT. ${ }^{45}$

Somewhat mysteriously, the $\mathrm{AB}$ added at the very end of this long discussion about compliance that it was not expressing 'any opinion on the question of whether actions to liquidate duties that are based on administrative review determinations issued before the end of the reasonable period of time, and that have been delayed as a result of judicial proceedings, fall within the scope of the implementation obligations of the United States, as we do not need to do so in the context of our analysis of this issue in this case'. ${ }^{46}$ The $A B$ then applied this reasoning to the facts of the different cases/reviews before it to consistently conclude that any action taken after the end of the RPT based on zeroing, even actions that derive mechanically from prior review determinations and actions not setting forth any forward cash deposit, are WTO-inconsistent.

\section{Sunset reviews}

As regards the various sunset reviews that were challenged, the $\mathrm{AB}$ referred to its prior report on US-Continued Zeroing to find that it is premature to challenge a sunset review when only USDOC has made a likelihood-of-dumping determination 'considering that such preliminary results could be modified by the final results' ${ }^{47}$ or when such reviews were still pending before the USITC (US International Trade Commission) and it had not yet made its likelihood-ofinjury determination. It further held that if sunset reviews, even when based on zeroing, led to the revocation of the measure, the Panel was right not to have considered such reviews:

As we have noted above, these are compliance proceedings and the issue before the Panel was whether the United States had failed to comply; that is, the Panel was called on to establish whether the USDOC's determinations in these sunset reviews had any impact on compliance by the United States. We consider that the USDOC's affirmative final likelihood-of-dumping determinations in these sunset reviews did not ultimately undermine compliance by the United States with the

44 Ibid., para. 309.

45 Ibid., para. 311.

46 Ibid., para. 314.

47 Ibid., para. 374. 
recommendations and rulings of the DSB, considering that the anti-dumping duty orders were revoked at the end of the sunset reviews with an effective date of 7 March 2007. We consider this to be the case even assuming that the European Communities had demonstrated that these likelihood-of-dumping determinations relied on margins of dumping calculated using zeroing. ${ }^{48}$

What was important to the $\mathrm{AB}$ was the fact that 'the sunset reviews resulted in revocation orders and that these revocation orders became effective on a date prior to the end of the reasonable period of time'. ${ }^{49}$

\section{Failure to comply - time gap}

The AB upheld the Panel's refusal to make findings in respect of the US failure to take certain action by the end of the RPT when implementing measures were subsequently taken and adopted before the establishment of the implementation Panel. The $\mathrm{AB}$ agreed that any findings in respect of such noncompliance which was remedied prior to the establishment of a 21.5 DSU Panel would not be pertinent:

In this case, the Panel acted in a manner consistent with the objective of securing a positive and effective solution to the dispute, and did not exceed the bounds of its discretion when, in its analysis of whether the United States had complied with the recommendations and rulings of the DSB, it took into account implementation actions taken subsequent to the expiry of the reasonable period of time but before the Article 21.5 Panel was established.

When an Article 21.5 panel makes a finding that a WTO Member has not complied with the recommendations and rulings of the DSB in the original proceedings, the implication of that finding is that the WTO Member remains subject to obligations flowing from the recommendations and rulings issued by the DSB in the original proceedings. However, if the compliance panel finds that compliance has been achieved at the time of its establishment, but not at the end of the reasonable period of time, the responding WTO Member will not need to take additional remedial action. ${ }^{\mathbf{5 0}}$

\section{Prior nonchallenged aspects of the original measures}

The $\mathrm{AB}$ found that the fact that part of the original measure was previously not challenged or not found to be WTO-inconsistent because no final ruling was

48 Ibid., para. 380.

49 Ibid., para. 380. In respect of another sunset review in which both the USDOC and the USITC had made their final determinations but the actual continuation of the duty was only made effective through a continuation order after establishment of the compliance Panel, the AB considered that this sunset review should have been reviewed by the Panel since this continuation order did not change the essence of the measure in question and that this order risked undermining compliance by the United States. The AB concluded that this sunset review was inconsistent with the US obligations under the AD Agreement.

50 Ibid., paras. 411-412. 
made in this respect does not mean that it cannot be challenged in 21.5 DSU proceedings :

We disagree with the notion that a Member may be entitled to assume in Article 21.5 proceedings that an aspect of a measure that was not challenged in the original proceedings is consistent with that Member's obligations under the covered agreements ... If certain claims against aspects of a measure were not decided on the merits in the original proceedings, they are not covered by the recommendations and rulings of the DSB and, therefore, a Member should not be entitled to assume that those aspects of the measure are consistent with the covered agreements. ${ }^{51}$

According to the $\mathrm{AB}$, allowing a complaining Member to make a case that it did not establish in the original proceedings would not provide it with an unfair 'second chance', nor would it compromise the finality of the DSB's recommendations and rulings. The $\mathrm{AB}$ was of the view that "While claims in Article 21.5 proceedings cannot be used to re-open issues that were decided on substance in the original proceedings, the unconditional acceptance of the recommendations and rulings of the DSB by the parties to a dispute does not preclude raising new claims against measures taken to comply that incorporate unchanged aspects of original measures that could have been made, but were not made, in the original proceedings. ${ }^{52}$ It thus reversed the Panel's contrary finding. The AB did qualify its position, putting it in the context of a 'new' implementation measure that incorporates unchanged aspects of the original measure that are not separable from the implementation measure.

5. 'All others' rate

On the question of the 'all others' rate in situations where all margins are determined on the basis of facts available or are below de minimis, the $\mathrm{AB}$ reversed the Panel's finding that in such cases Article 9.4 of the AD Agreement does not impose any limits on the discretionary powers of the investigating authority. However, the $\mathrm{AB}$ offered no solution to the obvious problem posed by the text of Article 9.4:

In this regard, we do not agree with the Panel's statement that, in situations where all margins of dumping are either zero, de minimis, or based on facts available, Article 9.4 'simply imposes no prohibition, as no ceiling can be calculated. ${ }^{53}$ In our view, the fact that all margins of dumping for the investigated exporters fall within one of the categories that Article 9.4 directs investigating authorities to disregard, for purposes of that paragraph, does not imply that the investigating authorities' discretion to apply duties on non-investigated exporters is unbounded. The lacuna that the Appellate Body recognized to exist in Article 9.4 is one of a specific method. Thus, the absence of guidance in Article 9.4

51 Ibid., para. 424.

52 Ibid., paras. $426-427$.

53 Panel Report, US-Zeroing (EC) (Article 21.5 DSU), para. 8.283 (original emphasis). 
on what particular methodology to follow does not imply an absence of any obligation with respect to the 'all others' rate applicable to non-investigated exporters where all margins of dumping for the investigated exporters are either zero, de minimis, or based on facts available. In any event, the participants have not suggested specific alternative methodologies to calculate the maximum allowable 'all others' rate in situations where all margins of dumping calculated for the investigated exporters fall into the three categories to be disregarded, and we do not need to resolve this issue to dispose of this appeal. ${ }^{54}$

Interesting is also the AB's position that the possibility of determining margins on the basis of facts available under Article 6.8 'applies exclusively to those "interested parties" from which information was required, rather than to those parties from which information was not requested. Thus, the disciplines in relation to the application of "facts available" under Article 6.8 and Annex II do not apply to non-investigated exporters that eventually will be subject to the "all others" rate. $^{, 55}$

\section{US-Zeroing (Japan)}

On 20 May 2009, the United States filed a Notice of Appeal, ${ }^{56}$ challenging several aspects of the Panel Report. First, the United States argued that a review which was not yet terminated at the time of Japan's request for establishment of a Panel was not within the Panel's terms of reference. The United States considered that the general terms 'any subsequent closely connected measures' was not sufficiently specific in the sense of Article 6.2 DSU. In addition, the United States argued that this review was a 'future measure' that had not yet come into existence at the time of Japan's Panel request, and therefore could not be considered to be part of the Panel's terms of reference.

Second, in respect of the determination of the relevant moment in time for determining compliance, the United States considered that the Panel's basic error consisted of using the date of collection of duties as the determining factor for assessing whether the United States had brought itself into compliance. According to the United States, it is rather the date of importation that prevails. This implies that reviews relating to imports that entered the United States prior to the expiration of the RPT and that apply zeroing are not inconsistent with the US obligations, even when this leads to the collection of duties after the RPT. In addition, the United States submits that, even if the date of liquidation was relevant for assessing compliance, liquidation actions that take place after the RPT as a result of domestic litigation cannot provide a basis for a finding of noncompliance. Relying on the $\mathrm{AB}$ Report in US-Zeroing (EC) (EC-Article 21.5), the United States further maintains that the liquidation actions that have been delayed as a result of

54 Appellate Body Report, US-Zeroing (EC) (Article 21.5 DSU), para. 453.

55 Ibid., para. 459.

$56 \mathrm{WT} / \mathrm{DS} 322 / 32$. 
domestic litigation cannot be said to 'derive mechanically' from the challenged periodic reviews, and therefore cannot be deemed to be WTO-inconsistent. ${ }^{57}$ In addition, the United States challenges the finding concerning Reviews 4, 5, and 6, on the grounds that these reviews did not have effects after the expiration of the RPT because assessment of duties calculated in these reviews was enjoined prior to the conclusion of the RPT and continues to be enjoined.

\section{Appellate Body Report}

The $\mathrm{AB}$ rejected the US arguments on both issues.

1. Inclusion of reviews not terminated at the time of the request for establishment

The $A B$ rejected the US appeal considering that in the context of this dispute the challenged review was sufficiently clearly identified in the request that expressly referred to the previous eight reviews in respect of the same anti-dumping order. It also 'agree[d] with the Panel's conclusion that "a finding that the phrase 'subsequent closely connected measures' satisfies the terms of Article 6.2 would not violate any due process objective of the DSU'", ${ }^{58}$ Regarding the formalistic US argument that the DSU does not allow for the inclusion of such 'future measures' within a Panel's terms of reference, ${ }^{59}$ the $\mathrm{AB}$ reasoned as follows:

We observed earlier that the requirements of Article 6.2 must be read in the light of the specific function of Article 21.5 proceedings and that the 'specific measures at issue' to be identified in these proceedings are measures that have a bearing on compliance with the recommendations and rulings of the DSB. A measure that is initiated before there has been recourse to an Article 21.5 panel, and which is completed during those Article 21.5 panel proceedings, may have a bearing on whether there is compliance with the DSB's recommendations and rulings. Thus, if such a measure incorporates the same conduct that was found to be WTOinconsistent in the original proceedings, it would show non-compliance with the DSB's recommendations and rulings. To exclude such a measure from an Article 21.5 panel's terms of reference because the measure was not completed at the time of the panel request but, rather, was completed during the Article 21.5 proceedings, would mean that the disagreement 'as to the existence or consistency with a covered agreement of measures taken to comply' would not be fully resolved by that Article 21.5 panel. New Article 21.5 proceedings would therefore be required to resolve the disagreement and establish whether there is compliance. Thus, an a priori exclusion of measures completed during Article 21.5 proceedings could frustrate the function of compliance proceedings. It would also be inconsistent with the objectives of the DSU to provide for the 'prompt settlement of situations in which a Member considers that any benefits accruing to it directly or indirectly under the covered agreements are being impaired', as

57 Appellate Body Report, US-Zeroing (Japan) (Article 21.5 DSU), para. 148.

58 Ibid., para. 119.

59 Ibid., para. 120. 
reflected in Article 3.3, and to 'secure a positive solution to a dispute', as contemplated in Article 3.7. ${ }^{60}$ (footnotes omitted)

The AB agreed with the Panel that it was proper to include this review as it was 'necessary for the Panel to assess whether compliance had been achieved, and thereby resolve the "disagreement as to the existence or consistency with a covered agreement of measures taken to comply with the recommendations and rulings" ". ${ }^{61}$ It considered that "Review 9 had been initiated at the time the matter was referred to the Panel and was due to be completed during the Article 21.5 proceedings. Under these circumstances, we consider that the Panel was correct in finding that Review 9 was within its terms of reference, as doing so enabled it to fulfil its mandate to resolve the "disagreement" between the parties and determine, in a prompt manner, whether the United States had achieved compliance with the DSB's recommendations and rulings. ${ }^{32}$

\section{Relevant moment of time for assessing compliance}

The $\mathrm{AB}$ also rejected the US arguments on appeal in respect of the Panel's finding that the date of collection of duties is the determining factor for assessing whether the United States had brought itself into compliance. The AB first examined the scope and timing of the compliance obligations under Article 21.5 DSU and concluded that 'Article 21.3 requires that the obligation to implement fully the DSB's recommendations and rulings be fulfilled by the end of the reasonable period of time at the latest and, consequently, the WTO-inconsistent conduct must cease at the latest by that time'. ${ }^{63}$ The $A B$ then examined the first issue raised by the United States's appeal, i.e. whether the obligation to comply applies also in respect of imports that entered the territory of the implementing WTO Member prior to the expiration of the RPT, when matters concerning those imports have not been fully settled by the end of the RPT. It referred to its ruling in the US-Zeroing (EC) case and confirmed that the relevant date is not the date of importation as argued by the US:

Irrespective of the date on which the imports entered the territory of the implementing Member, the WTO-inconsistencies must cease by the end of the reasonable period of time. There will not be full compliance where the implementing Member fails to take action to rectify the WTO-inconsistent aspects of a measure that remains in force after the end of the reasonable period of time. Likewise, actions taken by the implementing Member after the end of the reasonable period of time must be WTO-consistent, even if those actions are in respect of imports that entered the Member's territory before the end of the reasonable period of time. Therefore, we agree with the Panel's statement that,

60 Ibid., para. 122.

61 Ibid., para. 125.

62 Ibid., para. 124.

63 Ibid., para. 158. 
'[i]f a measure found to be WTO-inconsistent is to be applied after the expiry of the reasonable period of time, that measure must have been brought "into conformity", irrespective of the date of entry of the imports covered by that measure'. ${ }^{64}$ (footnotes omitted)

Applying this test to the facts of the case it agreed with the Panel that the United States had failed to bring itself into compliance:

The measures at issue in the present case are periodic reviews of anti-dumping duty orders. The Panel explained that, in the United States' anti-dumping system, periodic reviews involve the determination of 'importer-specific assessment rates for previous entries imported during the review period' and 'exporter-specific cash deposit rates that will apply prospectively to future import entries'. Where the importer-specific assessment rates or cash deposits rates determined by the implementing Member are found to be WTO-inconsistent, that Member is under an obligation to rectify the inconsistencies. In order to comply fully with this obligation, the inconsistencies must be rectified by the end of the reasonable period of time. Where the periodic reviews cover imports that entered the implementing Member's territory prior to the expiration of the reasonable period of time, the WTO-inconsistencies may not persist after the reasonable period of time has expired. Thus, for example, importer-specific assessment rates that were found to be WTO-inconsistent may not remain in effect after the expiration of the reasonable period of time. In other words, the WTO-inconsistent conduct must cease completely, even if it is related to imports that entered the implementing Member's territory before the reasonable period of time expired. Otherwise, full compliance with the DSB's recommendations and rulings cannot be said to have occurred. ${ }^{65}$ (footnotes omitted)

An important part of the US argument was that this approach disadvantages WTO Members with retrospective anti-dumping systems, i.e. the United States. The $\mathrm{AB}$ rejected this argument considering that it 'is difficult to reconcile with the text of Article 9.3.2 of the Anti-Dumping Agreement, which requires that WTO Members with prospective anti-dumping systems provide a mechanism allowing importers to request refunds of any duty paid in excess of the margin of dumping' ${ }^{66}$ The $\mathrm{AB}$ explained its view as follows:

Therefore, where actions or omissions relating to a refund procedure are challenged both domestically and in WTO dispute settlement, delays in the completion of a refund procedure until after the end of the reasonable period of time cannot be excluded. Should such a refund procedure not be completed before the end of the reasonable period of time, a WTO Member with a prospective antidumping system would have compliance obligations in respect of that refund procedure concerning past imports. Such a Member would thus find itself in a situation similar to that of an implementing Member applying a retrospective

64 Ibid., para. 160.

65 Ibid., para. 161.

66 Ibid., para. 166. 
anti-dumping system. This confirms that, under both retrospective and prospective anti-dumping systems, entries made prior to the expiration of the reasonable period of time also may be affected by compliance obligations. As a consequence, we disagree with the United States that disregarding the date of entry of the merchandise for purposes of determining compliance would result in retrospective anti-dumping systems being treated less favourably than prospective anti-dumping systems. ${ }^{67}$

The $\mathrm{AB}$ also recalled that the obligation of Article 9 relates to the imposition and collection of duties which must comply with the obligations of the AD Agreement, including the prohibition on zeroing. Therefore, according to the $\mathrm{AB}$, 'Where a WTO Member has been found to have violated the Anti-Dumping Agreement and the GATT 1994 by using zeroing in a periodic review, it fails to comply with the DSB's recommendations and rulings if it collects, subsequent to the expiration of the reasonable period of time, anti-dumping duties based on rates that were determined in the periodic review using zeroing. If it did so, the obligation in Article 9.3 that " $[t]$ he amount of the anti-dumping duty shall not exceed the margin of dumping as established under Article 2" would not be respected. ${ }^{\mathbf{6} 8}$

The second aspect of the US appeal on this matter concerned the impact on compliance of domestic-court proceedings by which reviews are suspended until after the expiration of the RPT. As phrased by the AB 'the question is whether actions or omissions that occur after the expiration of the reasonable period of time due to domestic judicial proceedings are excluded from the implementing Member's compliance obligations' ${ }^{69}$

The United States had argued that the compliance obligation had to be read in the light of the obligation in Article 13 of the AD Agreement of allowing for

67 Ibid., para. 166.

68 Ibid., para. 168. This is similar to what would occur if zeroing were allowed in periodic reviews, while being disallowed in the original anti-dumping determination. As the Appellate Body explained in US-Stainless Steel (Mexico): ' a reading of Article 9.3 of the Anti-Dumping Agreement that permits simple zeroing in periodic reviews would allow WTO Members to circumvent the prohibition of zeroing in original investigations that applies under the first sentence of Article 2.4.2 of the Anti-Dumping Agreement. This is because, in the first periodic review after an original investigation, the duty assessment rate for each importer will take effect from the date of the original imposition of anti-dumping duties. Consequently, zeroing would be introduced although it is not permissible in original investigations' (Appellate Body Report, US - Final Anti-Dumping Measures on Stainless Steel from Mexico, WT/DS344/ $\mathrm{AB} / \mathrm{R}$, adopted 8 May 2008, para. 109).

69 Appellate Body Report, US-Zeroing (Japan) (Article 21.5 DSU), paras. 170-171. It is important to understand that in the US system, liquidation instructions are given following the conclusion of the periodic review. However, where litigation is initiated before the USDOC has issued the liquidation instructions and a US court enjoins liquidation, the USDOC will issue instructions to Customs ordering it not to liquidate the entries during the pendency of domestic litigation. If litigation is initiated after the issuance of liquidation instructions but before actual liquidation, the court may issue an injunction, and the USDOC will send instructions to Customs notifying it of the injunction and will require Customs to suspend liquidation of the entries until the conclusion of domestic litigation. Upon the conclusion of domestic litigation and the consequent lifting of any applicable injunctions, the USDOC will send instructions to Customs ordering liquidation of the entries in accordance with the court's decision and Customs will collect duties accordingly. 
independent review by domestic tribunals of anti-dumping determinations. The $\mathrm{AB}$ rejected this argument in no unclear terms:

The fact that WTO Members are required to maintain independent review procedures for administrative anti-dumping actions does not exonerate them from the requirement to comply with the DSB's recommendations and rulings within the reasonable period of time. We see no conflict between the obligation to maintain independent review procedures under Article 13 and the obligation to comply with the DSB's recommendations and rulings. Accordingly, we do not consider that Article 13 provides support for the proposition that a WTO Member is excused from complying with the DSB's recommendations and rulings by the end of the reasonable period of time, where a periodic review has been challenged in that Member's domestic courts and this has resulted in the collection of duties being delayed. ${ }^{70}$

It also considered very relevant the requirement of prompt compliance of Article 21.3 DSU:

the very text of Article 21.3 indicates that the 'reasonable period of time' is an exception to immediate compliance, thus implying that further delays would not be justified, whatever the circumstances. In US-Zeroing (EC) (Article $21.5-E C)$, the Appellate Body stated that the 'implementing Member would be able to extend the reasonable period of time and delay compliance depending on when it chooses to undertake final duty assessment' if the approach based on the date of entry, as advocated by the United States, was followed. The Appellate Body also cautioned there that '[s]uch a result would deprive of meaning the notion of "reasonable period of time" in which a Member shall comply, as provided for in Article 21.3 of the DSU, and be contrary to the implementation mechanism of the DSU.' The same rationale is applicable in respect of delays in implementation due to domestic judicial proceedings. Such delays in implementation cannot exonerate a Member from its compliance obligations and are not consistent with the overall objectives of 'prompt' and 'immediate' compliance in Articles 21.1 and 21.3. (emphasis added; footnotes omitted) ${ }^{71}$

The $\mathrm{AB}$ rejected the US argument that 'the timing of liquidation is controlled by the independent judiciary and not the administering authority' and that therefore it could not be blamed for not respecting the RPT. The AB recalled that a WTO Member 'bears responsibility for acts of all its departments of government, including its judiciary', and concluded that 'the United States cannot seek to avoid the obligation to comply with the DSB's recommendations and rulings within the reasonable period of time, by relying on the timing of liquidation being "controlled by the independent judiciary" '.72 Finally, the AB was not persuaded by the 
US argument that the initiation by private parties of domestic judicial proceedings is relevant for determining the scope of US compliance obligations.

\section{Legal analysis}

The two 'zeroing' Reports discussed above do not concern the question of the legitimacy of zeroing. Rather, the issues before the $A B$ in these cases related to the way in which adverse rulings in respect of US anti-dumping measures have to be implemented. Thus, the implementation-related issues of these Reports are mainly of interest to trade-remedy lawyers, especially those dealing with US anti-dumping measures. They do not raise any systemic legal issues of major importance to the implementation of WTO rulings, although as discussed in the next section, they do raise some more general issues regarding determination of compliance with WTO rules and rulings from an economic perspective.

\section{Periodic reviews as 'measures taken to comply'}

The main issue in this case related to the manner in which the United States was supposed to have implemented adverse rulings relating to zeroing in anti-dumping investigations. The implementation issues that arose are specific to the United States, which is the only country that uses a retrospective anti-dumping system rather than a prospective anti-dumping system. To put it simply, in a retrospective system, the original investigation into dumping, injury, and the causal link will allow for the imposition of anti-dumping measures and will set the amount of cash deposits for imports entering the country following imposition of the measure. The actual amount of duties to be paid, however, will normally only be determined in the course of a periodic (yearly) review of the measure. At the time of the review, it will be examined whether, in the course of the past review period, imports were actually entering the country at dumped prices and what the level of the dumping margin was. Based on the level of the margin of dumping - which may well be higher than the margin of dumping determined at the time of the original investigation - a definitive determination of the amount of duties that are due will be made and on that basis the duties will be collected ('liquidated'). At the same time, a cash-deposit requirement will be imposed for future imports entering the country, the level of which is set on the basis of the margin of dumping that was determined at the time of the review. And that story repeats itself until the end of the normal five-year life cycle of the anti-dumping order when a sunset review may be conducted to examine whether there is a likelihood of continuation or recurrence of dumping causing injury if the duty were removed.

The EU and Japan challenged a number of original determinations and a number of periodic reviews in which dumping was determined by the US authorities using the WTO-inconsistent zeroing methodology. Following the original dispute in which the EU and Japan prevailed, the United States revisited the dumping calculations of the original investigations to determine whether, even without zeroing, 
dumping existed. If so, the measure continued to exist. The United States considered that it was not required to do anything in case subsequent periodic reviews had superseded the reviews that had originally been challenged. And it thus continued to zero in the course of these subsequent reviews. Obviously, this type of implementation was considered to be completely meaningless to the EU and Japan since, at the end of the day, their exporters were still required to pay duties based on margins of dumping determined through the use of zeroing.

The EU and Japan argued that these subsequent reviews in which the United States continued to zero were 'measures taken to comply' with the DSB ruling and could thus be examined by the implementation Panel in the context of an Article 21.5 DSU implementation dispute. As explained above, the Panel and AB agreed, applying the 'close nexus' test: the subsequent reviews conducted in the context of the same AD orders that had been the subject of the original dispute were sufficiently closely linked in terms of the nature, effect, and timing with the previously challenged measures that they could be seen as 'measures taken to comply'. The AB considered that this was true even for reviews that had been initiated well before the adoption of the Reports they were supposed to be 'complying with'.

We do not disagree with the outcome of this dispute and consider that ultimately the $\mathrm{AB}$ got it right. However, we do find that there is something bizarre about the AB's reasoning - how can a measure be a 'measure taken to comply' with a Report when that Report has not even been adopted or even issued? It is simply counterintuitive to treat reviews initiated and completed even before adoption of the Panel and $\mathrm{AB}$ Reports as measures 'taken to comply' with these Reports.

The $\mathrm{AB}$ explained that any measure adopted in the course of the dispute but before adoption of a Report could well impact on the country's compliance with its WTO obligations and should therefore be treated as a 'measure taken to comply' if a sufficiently close link existed between the originally challenged measure and the alleged measure taken to comply. However, we wonder whether there was actually any need to develop the rather complicated reasoning that the $\mathrm{AB}$ adopted in this case in respect of these reviews arguing that they were 'measures taken to comply'. In our view, the problem could have been dealt with in a simple and straightforward manner, avoiding problematic statements such as the one referred to before about measures complying with Reports even before the Report was released let alone adopted.

What was the original problem? That anti-dumping duties were imposed based on a WTO-inconsistent method for determining dumping; that cash deposits were required and duties were collected on the basis of dumping margins calculated using this same methodology. We recall that GATT Article II allows for the imposition of duties and charges only up to the level of the bound tariff and that 'other charges' may only be imposed if they are included in the Schedule of Concessions. GATT Article II. 2 allows, by way of exception, for the imposition of anti-dumping measures, as long as they are imposed in a GATT-consistent 
manner. Similarly, GATT Article VI and the WTO AD Agreement allow for the imposition of anti-dumping measures on imports of certain countries only, thus deviating from the general MFN rule of GATT Article I, and set forth certain disciplines in terms of the determination of the margin of dumping. The United States lost the original dispute because the 'zeroing' method for calculating the margin of dumping that was used in a number of anti-dumping cases was considered to be WTO-inconsistent. The United States was to correct this error and was given a reasonable period of time to do so. Upon expiry of this period of time, the question is whether the United States has complied with the ruling of the DSB that its method of determining margins of dumping and thus of imposing anti-dumping duties based on zeroing is WTO-inconsistent. It seems normal to examine the situation at the end of the RPT to determine whether duties are still in place, whether cash deposits are still required, and whether duties are still being collected in respect of the originally challenged AD orders and this based on the WTO-inconsistent method of zeroing. If that is the case - and the United States did not deny that this was indeed the case - then it seems pretty clear that the United States has failed to comply with the DSB ruling. What can be so complicated about this conclusion that would warrant a lengthy discussion about the meaning of the term 'measures taken to comply'?

The basic question is whether there exists compliance. The imposition of charges (cash deposits) and the collection of additional import duties (anti-dumping duties) based on zeroed margins clearly demonstrate, not that the measures taken to comply were WTO-inconsistent, but that no measures were taken to comply. The existence of such GATT/WTO-inconsistent cash deposits and duties is inconsistent with the AD Agreement, GATT Article VI, and thus ultimately also with GATT Article II. Interestingly, this is also what the AB appears to ultimately find: that any action taken after the expiry of the RPT that concerns the same subject matter and is not consistent with the WTO obligations of a Member demonstrates a failure to comply with the DSB ruling dealing with that subject matter.

In our view, the AB inappropriately was led down a pseudo-technical path distinguishing between original determinations, periodic reviews, new periodic reviews, sunset reviews, prospective systems, retrospective systems, cash deposits, duty collection, duty liquidation, etc. If this had not been an anti-dumping dispute but a simple tariff violation, it is very doubtful that the $\mathrm{AB}$ would have complicated matters as much as it did in this case. In addition, its acceptance of these technical nonarguments required it to effectively disregard one of the three tests it had itself developed for determining whether there existed a sufficient nexus between the measure challenged and the 'measure taken to comply': the timing of the measure. Clearly, the sensible rationale for including the 'timing' of any measure as part of the analysis of whether a new measure was a measure taken to comply and thus part of the implementation Panel's terms of reference was whether it was taken following release and/or adoption of the Report. The AB in these zeroing cases rejected the idea that timing is a determinative factor but failed to explain what 
role, if any, this factor should play if it actually does not matter whether the measure was adopted even before the release of the Report to the parties. It seems that the three-pronged 'nexus' test that was developed by the $\mathrm{AB}$ in the context of Article 21.5 implementation disputes has effectively been reduced to a twopronged test in these zeroing cases.

\section{Timing of compliance - any action following the expiry of the RPT is captured}

A second important clarification offered by the $\mathrm{AB}$ in these cases concerned the importance of the end of the RPT. We are of the view that the AB was right that the relevant moment in time for determining compliance is the end of the RPT and that any action taken after the end of the RPT that is inconsistent with a country's WTO obligations demonstrates a failure to comply. For many WTO Members, this solution is obvious and there is no reason why the same conclusion would not apply to the United States as well.

This being said, we agree with the United States that this puts it at a disadvantage in comparison with Members that use the prospective system of duty collection. Under a prospective system, imports entering the country prior to the end of the RPT will be subject to the payment of duties in a final manner and such duties will effectively escape the WTO disciplines since they were collected prior to the end of the RPT. In a retrospective system, such duties are collected only in a provisional manner. If a subsequent review that determines the final duty liability is conducted after the end of the RPT, it will be subject to the WTO disciplines and the duties may not be collected in full. In sum, it is clear that the AB's approach implies that the United States will have to accept the consequences of its retrospective system, which disadvantages the United States in this particular case. However, in many other ways, this retrospective system has important 'advantages' from the point of view of protecting the domestic industry. There are good reasons why domestic industry associations argue so strongly in favour of maintaining this administratively burdensome system, the usefulness of which is currently under discussion in the United States.

In this respect, it is not clear that the AB's approach does not disadvantage the retrospective system. The $\mathrm{AB}$ argues that in a prospective system (used everywhere else in the world), interested parties may also request refunds after the end of the RPT. However, such refund requests are rather uncommon. Moreover, we wonder whether an importer could request the refund of excess duties paid in the course of the RPT. After all, throughout the RPT a Member would be allowed to continue to act in a manner inconsistent with its WTO obligations without there being any remedy. On what basis would such a refund be requested? The Panel's position on this question seems more appropriate: that every system has its advantages and disadvantages and that each Member must accept the consequences, whether good or bad, of the system it adopts. This was essentially also the view adopted in the context of the US-FSC (Foreign Sales Corporations) dispute where, to put it 
somewhat simplistically, the United States suffered the negative consequences of the international tax regime that it had adopted.

A related matter of some importance concerns the impact that delays caused by domestic-court proceedings have on compliance. We consider that the $\mathrm{AB}$ was right to say that it does not matter why liquidation was delayed since any action taken after the expiry of the RPT has to be WTO-consistent. But why then did the $\mathrm{AB}$ not immediately say so when this first came before it in the Article 21.5 US-Zeroing $(E C)$ case? After all, it is merely the logical consequence of its general approach to focus on the date of the expiry of the RPT and on the actions adopted since that time, rather than on the legal basis for the action in isolation (the determination of the margin of dumping).

In the Article 21.5 US-Zeroing (EC) case, the $\mathrm{AB}$ stated that it did 'not express any opinion on the question of whether actions to liquidate duties that are based on administrative review determinations issued before the end of the reasonable period of time, and that have been delayed as a result of judicial proceedings, fall within the scope of the implementation obligations of the United States, as we do not need to do so in the context of our analysis of this issue in this case '. ${ }^{73}$ This was surprising since its entire reasoning, which focused on the fact that any action taken after the expiry of the RPT has to be WTO-consistent, clearly suggested that it had in fact expressed itself on this issue.

This is a typical example of the AB throwing in a statement to say that it is not expressing a view on a certain matter when it actually has already done so, thereby creating the impression that it may adopt a different approach with respect to this question. Why else would you add a paragraph saying that your views should not be read to imply that this or that is also inconsistent? The signal that is being given is clearly that a different conclusion may need to be drawn in such circumstances. But then, six months later when the issue is again before the AB in the Article 21.5 US-Zeroing (Japan) case, the $\mathrm{AB}$ does actually follow its own logic and does consider that such actions are also WTO-inconsistent irrespective of whether the delay was caused by court proceedings. Why did the AB not say that before and why did it suggest that a different outcome may actually be warranted if 'security and predictability' are the main guiding principles of the dispute-settlement system ? $^{74}$

This is not the first time the $\mathrm{AB}$ has done so. Its entire zeroing jurisprudence is the consequence of such failure to express itself clearly in respect of this issue from the first time the issue was raised before it. The AB stated that it did not express a view on whether zeroing was inconsistent with the fair-comparison requirement of Article 2.4 in, for example, US-Zeroing $(E C)$ and stated that it was not expressing a view on whether zeroing in transaction-to-transaction comparisons is also prohibited in US-Softwood Lumber V, to later find that zeroing is unfair and that 
zeroing violates the fair-comparison requirement. This false restraint by the $A B$ is not consistent with its important role in securing the predictability of the system.

\section{The 'all others' rate - how to deal with a loophole?}

Another missed opportunity in clarifying the rules has been the AB's reasoning on the 'all others' problem in this case. Article 9.4 of the AD Agreement provides that the 'all others' rate that applies to nonsampled exporters should not exceed the average margin of dumping, while excluding margins that are zero or de minimis or based on facts available. But what to do if all margins are either zero or de minimis or are based on facts available? That was the problem the Panel was confronted with. It reached the conclusion that in such a case there is no obligation to respect under Article 9.4. The Panel found that Article 9.4 merely 'establish[es] a methodology for the calculation of a "ceiling" which the "all others" rate may not exceed', but does not 'specify a method for or imposes disciplines on the calculation of the "all others" rate itself. "75 According to the Panel, in cases where all the margins of dumping for the investigated exporters are zero, de minimis, or based on facts available, 'there are simply no margins of dumping from which the investigating authority ... may calculate the maximum allowable 'all others' rate and therefore, in such circumstances, 'Article 9.4 simply imposes no prohibition, as no ceiling can be calculated. ${ }^{76}$

The AB disagrees:

The lacuna that the Appellate Body recognized to exist in Article 9.4 is one of a specific method. Thus, the absence of guidance in Article 9.4 on what particular methodology to follow does not imply an absence of any obligation with respect to the 'all others' rate applicable to non-investigated exporters where all margins of dumping for the investigated exporters are either zero, de minimis, or based on facts available. In any event, the participants have not suggested specific alternative methodologies to calculate the maximum allowable 'all others' rate in situations where all margins of dumping calculated for the investigated exporters fall into the three categories to be disregarded, and we do not need to resolve this issue to dispose of this appeal. ${ }^{77}$

Thus, the AB considers that Article 9.4 imposes an obligation, but it refuses to clarify what this obligation is and what an authority is to do in such circumstances. It hides behind the fact that no alternative methodologies have been suggested by the parties. In our view, it would have been very useful and even necessary given the objective of providing 'security and predictability to the multilateral trading system' had the AB clarified its view of what, if any, obligation Article 9.4 imposes in such circumstances. Unfortunately, the AB said A without saying B.

75 Panel Report, US-Zeroing (EC) (Article 21.5 DSU), para. 8.281.

76 Ibid., para. 8.283 (original emphasis).

77 Appellate Body Report, US-Zeroing (EC) (Article 21.5 DSU), para. 453. 


\section{Economic perspectives and policy considerations}

Anti-dumping-related disputes - both zeroing and others - accounted for a significant share of the WTO dispute-settlement caseload-some $30 \%$ on average during 2001-2008, compared to $15 \%$ in the 1995-2000 period (Bown and McCulloch, 2010). This is a reflection of the frequency with which AD measures are imposed by WTO members. The instrument is increasingly employed by 'nontraditional' users - emerging market and other developing countries - as well as the EU, United States, and other OECD [Organisation for Economic Co-operation and Development] members. The frequent recourse to the DSU is also a reflection of the detailed rules of the game that are contained in the AD Agreement, which are the result of efforts by targeted exporting countries over the past $20+$ years to discipline specific practices that at some point in time were employed by the major users - the EU and United States in particular - to protect domestic industries.

Previous studies of zeroing disputes that have been undertaken for the ALI (American Law Institute) project on the case law of the WTO have analyzed many of the economic dimensions of the practice of zeroing in some depth, clarifying how zeroing inflates margins and documenting how the different varieties of zeroing methodologies employed by the Department of Commerce operate (Bown and Sykes, 2008; Prusa and Vermulst, 2009). We have little to add in terms of analysis of the economics of zeroing and we will not seek to do so in this paper.

From an economic perspective, a first-order question is how much zeroing matters. It is well known that investigating authorities can be and often are 'creative' in pursuing AD investigations in ways that increase the likelihood of finding positive dumping margins and that inflate average calculated margins. From this perspective, it is somewhat puzzling why the specific question of zeroing is the focus of such intense dispute-settlement activity. One reason is that the United States is currently the only jurisdiction to use zeroing. Another is that the United States is a major user of anti-dumping. Anti-dumping affects only a small share of global trade - much less than $1 \%$ - but the United States accounts for about $10 \%$ of global AD actions and is a major market for many exporters.

Although several developing countries, most notably India, have become more frequent AD users (India accounted for 15\% of global investigations in 2009, up from less than $4 \%$ in 1995), ${ }^{78}$ their increased 'market share' has come at the 'expense' of a small number of traditional users such as the EU and South Africa. These two WTO members accounted for some $30 \%$ of all AD investigations in the mid 1990s, as compared to $9 \%$ in 2009 . The US share of total investigations in contrast has been quite stable at $10 \%$, although the US share of AD measures imposed has declined relative to the second half of the 1990s when it was on the order of $15 \%$ of the global total. In recent years, the US share of AD measures in force has averaged around $10 \%$ of the global total. On average, $4.6 \%$

78 Unless noted otherwise, data reported in this paragraph are from the WTO website. 
of all US imports by value were subject to temporary trade barriers in the 1997-2007 period, with AD accounting for over $80 \%$ of the products affected (Bown, 2010).

Thus, US anti-dumping is a significant market-access concern. How much zeroing matters in this regard depends on the extent to which it increases dumping margins. Empirical analysis of this question is very scarce. Nye (2009) estimates that zeroing accounts for only 2.5 percentage points of an average $47 \%$ antidumping duty imposed by the United States in a sample of cases, suggesting that zeroing is of marginal relevance from an economic perspective. Bown and Prusa (2010) come to a very different conclusion, arguing that if the United States was to cease using zeroing, a significant number of AD measures would be removed altogether. They determine that up to half of all US AD measures that have been contested in WTO cases would have to be removed (because there would not be a positive $\mathrm{AD}$ margin anymore) and that the duties in the other cases would fall significantly. ${ }^{79}$ While many of the duties that would be removed are relatively low - mostly in single digits - the uncertainty created by zeroing for exporters that confront substantial variation in export prices can have a significant chilling effect on trade. It is not just the dumping margin that matters but the probability of being subject to an anti-dumping investigation and the associated direct costs and chilling effects/uncertainty generated by the reactions of importers/ buyers.

The Bown and Prusa analysis helps to explain the amount of time and resources that have had to be devoted by the DSB to the issue of zeroing and the continuing expansion of the zeroing caseload. It matters for the affected exporters. As of the time of writing, zeroing cases have accounted for $20 \%$ of all AB cases, and about half of all Art. 21.5 DSU compliance cases. The recurring cases on zeroing are a problem, both for the system and for affected exporters. For the trading system, the recurring zeroing cases are a problem because repeated cases against a member that is not willing to comply can only reduce the perceived value of the institution. The importance of this dimension may increase the longer the Doha Round goes nowhere - as it raises the relative profile of the DSU as the part of the WTO that does work. For exporters, the lack of compliance by the United States implies continuing uncertainty regarding the conditions of market access in a large economy, while for the WTO system the repeated zeroing cases imply a misallocation of scarce resources given that the legal issues have been settled. ${ }^{80}$ Noteworthy in

79 This estimate is most likely an upper bound regarding the effects of zeroing on margins (presumably there is a selection effect).

80 However, it also needs to be pointed out that the process has had positive results. The first zeroing case (against the EC) was brought in 1998, and the EC eventually brought its AD regime into compliance in this respect, after having gone through an Art. 21.5 Panel (Janow and Staiger, 2003; Grossman and Sykes, 2006). In the case of the United States, zeroing is no longer applied by the United States in investigations. Of course, the problem is that the stock of past $\mathrm{AD}$ orders in the United States is large so that 
this regard is that five new dispute-settlement cases were brought to the WTO following the two Art. 21.5 cases that are the subject of this paper: by Brazil, Thailand, Mexico, Korea, and Vietnam - the last two in May 2010. Vietnam's case is the first this country has brought to the WTO, and is particularly noteworthy because it is treated as a nonmarket economy by the United States for AD purposes - so that there are many other ways the Department of Commerce can determine high dumping margins.

\section{Needed: more effective surveillance and analysis}

The role of the compliance Panels that are the subject of this paper was to determine whether the United States took action (implemented new measures) to become compliant with the AD Agreement. They concluded that the United States had not done so. As of the time of writing, both the EU and Japan had launched Art. 22.6 DSU proceedings, seeking authorization to retaliate against the United States for the losses incurred as a result of noncompliance by the United States. Paralleling the limited economic analysis of the effects of zeroing discussed above, the parties have wildly different estimates of the economic impacts of US zeroing, with the EU claiming upwards of $\$ 300$ million per year and the United States arguing it is closer to one-hundredth of that figure. Much will depend on the answer to the question posed above - i.e. the extent to which the use of zeroing in each case inflated the calculated dumping margin. The availability of information on this matter (more accurately, the lack thereof) will affect the feasibility of generating an accurate estimate of the amount of compensation-cum-retaliation that is appropriate.

This information problem also applies at the compliance Panel stage. A fundamental problem affecting the efficacy of the DSU is that the process of determining if compliance has occurred is left to Panels that are required to limit their remit to the issues raised in the original Panel. What may be missing - and is in the case of zeroing - is information on what is being implemented by the country found to have violated the WTO. For example, it is not clear whether the United States has in fact stopped using zeroing in original investigations. In at least one recent case, it has reportedly reverted to the practice. ${ }^{81}$ It is generally held that the United States continues to use zeroing in reviews, but it is not necessarily true that it does so in all reviews, and we do not know for all these reviews how much the dumping margin is affected by the practice.

the effect of ceasing to use zeroing in original investigations is limited due to the retroactive nature of the way duties are collected in the United States.

81 See Robert L. LaFrankie and Alicia Winston, 'US Government Expands the Use of Zeroing in Antidumping Investigations', 13 May 2010, commenting on Polyethylene Retail Carrier Bags from Taiwan: Final Determination of Sales at Less than Fair Value, 75 Fed. Reg. 14569 (26 March 2010). Available at http://www.mondaq.com/unitedstates/article.asp?articleid $=100460$ (last visited 27 September 2010). 
Zeroing affects not only EU and Japanese exporters. The first zeroing cases were brought by India and Brazil (against the EU), and, as noted above, more recently Thailand, Mexico, Korea, and Vietnam have now brought cases against the United States. It is rather inefficient if continued noncompliance by the United States results in recurring cases that are all dealing with an issue that has already been litigated. Rather than force individual exporting countries to initiate their own disputes, imposing unnecessary costs on the system and the countries concerned, it would be much better that if the United States has no intention of complying, the focus be put on compensating affected trading partners. Given that the US methodology is (can be) applied to all exporters, it would be more efficient to address this matter in a cooperative manner, rather than through a recurring series of cases that impose an excess burden on the DSB and on affected exporting countries and their exporters. ${ }^{82}$

Of course, the best way to resolve the matter would be for the United States to bring its measures into compliance. At the time of writing, the United States is reportedly still working towards this - which can be inferred from the decision in early September 2010 by the EU to request that the Art. 22.6 arbitration be suspended for a one-year period to provide the United States more time to reform its $\mathrm{AD}$ regime. ${ }^{83}$ In the absence of full compliance, one way to facilitate either an agreement with exporters on compensation or to reduce the costs to the WTO system of continued litigation is to make available information on a country-bycountry basis how much dumping margins have been affected by zeroing. That information can then be used to provide the affected countries with compensation, or be the basis for retaliatory action by the affected countries. At some point, if enough countries retaliate the United States may be induced to change its policy. However, as noted by Bown and Prusa (2010) the amounts involved - even though subject to great uncertainty at this point because of the lack of data - may not be large enough to have much of an impact on US exporters and thus to change the political-economy equilibrium in the United States on zeroing. But a system of transparent compensation-cum-retaliation based on the actual effects of zeroing would be better than another possible reaction to continued noncompliance by the United States: emulation by trading partners.

There are some parallels between the zeroing saga and the use of quantitative restrictions in the 1970s and 1980s that resulted in the Mutifibre Arrangement (MFA). Quantitative restrictions on textiles and clothing - which clearly violated the GATT but were accommodated by the system - emerged gradually but became widespread over time. A similar phenomenon could arise with zeroing, except in reverse, with developing countries adopting the practice. This would be very

82 It could be argued that allowing (forcing) a series of disputes to be brought by exporters, each of which ultimately result in retaliation - if a country thinks this is productive - also opens the United States up to accusations that it is not demonstrating good faith.

$83 \mathrm{See} \quad \mathrm{http} / /$ www.foxbusiness.com/markets/2010/09/08/eu-suspend-tariff-dispute-sanctions/, September 8, 2010 (last visited 28 September 2010). 
unfortunate. ${ }^{84}$ The textiles episode generated a GATT Textile Surveillance Body to monitor the implementation of the MFA and a Textiles Monitoring Body that was responsible for surveillance of all measures taken under the Uruguay Agreement on Textiles and Clothing (ATC) to liberalize trade in textiles and clothing. Agreement to establish a multilateral surveillance mechanism that documents the continued use by the United States of zeroing could increase the transparency of US policy in this area and help in quantifying the likely effects of zeroing on dumping margins. Such information would facilitate the work of both compliance and arbitration Panels, and help to inform the policymaking process in the United States.

The need for greater transparency goes beyond zeroing. AD has become by far the most frequently used contingent trade-policy instrument by WTO members and there is only limited multilateral surveillance of what countries are doing and what the effects are. The conventional wisdom is that the aggregate effects of AD are small. Egger and Nelson (2010) estimate that between 1960 and 2000 antidumping actions reduced imports in the countries applying these measures by 1.6 percentage points. It has long been pointed out by economists that such aggregate estimates ignore both the incidence of actions - the targeted exporters may be severely affected even if on average most are not - and the chilling effects of the uncertainty of market-access conditions created by the threat of $\mathrm{AD} .{ }^{85} \mathrm{~A}$ recent empirical analysis that explicitly considers the counterfactual - how much trade would be expected to be observed without the threat of $\mathrm{AD}$ - by incorporating information on the date when a country adopts $\mathrm{AD}$ legislation concludes that use of $\mathrm{AD}$ measures reduced imports by some $6-7 \%$ in active users, such as Brazil and India (Vandenbussche and Zanardi, 2010). However, the results also show that the reduction in imports resulting from $\mathrm{AD}$ actions in major users (which constitute a relatively small number of countries, albeit ones that are large) only partially offsets the increase in trade that resulted from overall liberalization of trade policy during the sample period in the countries considered. The estimated offsets ranged between one-sixth and one-half.

These results provide support for the notion that AD can be a useful (political) safety valve that allows countries to implement and sustain more general trade liberalization. As noted by Egger and Nelson (2010) this is an argument that has a long pedigree in the economic literature, dating back to Viner (1923). Finger and Nogués (2006) provide case-study evidence how AD and similar measures were used in Latin America as a proliberalization, safety-valve device. However, the trend in the prevalence of AD is clearly upward, with the 2009-2010 period seeing an additional boost in response to calls by firms for assistance to cope with the global economic crisis (Bown, 2010). The spread of AD may generate incentives for 'retaliation' - tit-for-tat responses by targeted countries - and this may serve to

84 This is true even if it eventually results in a multilateral solution as occurred in the case of the MFA: the costs of widespread use of zeroing are likely to be high for the most efficient producers.

85 These issues are recognized and discussed by Egger and Nelson (2010). 
constrain the growth of AD. There is some evidence that retaliation threats are one reason for the use of $\mathrm{AD}$ by major exporters, and that it may help restrain the use of AD by importing countries (Blonigen and Bown, 2003; Feinberg and Reynolds, 2006).

Whatever the dynamics may turn out to be, one conclusion we draw from the continuing zeroing saga is that greater transparency would be beneficial. What the WTO does in terms of surveillance is very narrow - essentially it is limited to a biannual compilation of AD investigations initiated and measures imposed without detail on trade volumes affected and no information on the methodologies used to determine dumping margins. The Temporary Trade Barriers database created by Chad Bown offers greater detail in terms of information on products affected and the amount of trade involved, ${ }^{86}$ but there is no effort currently to collect and report information on how margins were calculated. This is a major task that in practice will require the cooperation of the investigating authorities. As far as zeroing is concerned, if the United States were to decide to continue to zero in reviews and to go down the renegotiation/compensation route, such an exercise would need to be done just once, assuming that continued zeroing is limited to the existing stock of $\mathrm{AD}$ orders - i.e. to the reviews. Whatever the eventual outcome of this extended litigation and the decision of the United States regarding the use of zeroing, greater surveillance and information will be beneficial to the system.

\section{Concluding remarks}

To some extent the repeated recourse to the DSU on zeroing reflects ambiguities in the text of the AD Agreement, which in turn reflects serious, fundamental disagreement on this matter that could not be addressed in the Uruguay Round negotiations, and subsequent strong opposition by the United States towards efforts by the Appellate Body to 'write law' by interpreting an agreement that was somewhat ambiguous with respect to zeroing. While US noncompliance is the trigger for continuing litigation, this has been facilitated by the approach taken by the $\mathrm{AB}$ towards zeroing. Bown and Sykes (2008) argue that the strategy of the AB towards zeroing has been to decide each case narrowly as opposed to ruling on the legality of zeroing in general, i.e. independent of the case-specific context. This generated a series of cases that contest specific instances of zeroing methodologies along different segments of the AD 'supply chain'-original investigations, administrative reviews, sunset reviews, etc. The narrow and limited approach of the $\mathrm{AB}$ has been one determinant of the continuing stream of zeroing-related cases.

86 The anti-dumping data is available at http://econ.worldbank.org/ttbd/gad/ (last visited 29 September 2010). 
In the two Art 21.5 cases at hand, the AB has clearly stated that zeroing 'as such' is not permitted in either original investigations or reviews. The convoluted legal reasoning used by the $\mathrm{AB}$ to arrive at what is an obvious conclusion from a practical perspective - in that the United States continues to zero in reviews and does not contest this - is rather striking, but it has now been made clear that zeroing is disallowed, whether in investigations or in the administrative or sunset reviews that are used in the US retrospective system to determine applicable AD duties.

Continued noncompliance by the United States regarding zeroing in reviews creates a systemic risk as well as a continuing economic burden on affected exporters that confront higher AD duties than they otherwise would. Indeed, the limited extant research suggests that, absent zeroing, a substantial number of exporters would not be subject to AD measures at all. This is an area where greater transparency is important as it currently is virtually impossible to determine what the impact of zeroing is. If zeroing continues to be applied in reviews by the United States, affected exporting countries are confronted with the decision whether to launch disputes. A number of countries have already started down the road of invoking the DSU, and more may follow. This is arguably a waste of WTO resources. Continued noncompliance may also lead countries to start to zero themselves.

The best outcome of course would be that the United States reforms its regime to bring it into conformity with the AD Agreement. At the time of writing this, the prospects of this happening have increased, reflected in the request of the EU to suspend arbitration under Art. 22.6 to determine the magnitude of permitted retaliation so as to give the United States more time to reform its regime. In the absence of such an outcome, it would be desirable for the United States to provide information on the impacts that zeroing has on $\mathrm{AD}$ duty levels and either agree to compensate all affected exporters for the associated mark-ups (i.e., based on an analysis that 'but for' the zeroing the duty would have been $\mathrm{X}$ instead of $\mathrm{Y}$ ) or to facilitate (lower the costs for the WTO/DSB) the calculation of what is the appropriate level of retaliation that affected countries are permitted to apply if they choose to do so.

More generally, given the steady expansion in the number of countries using $\mathrm{AD}$, there is a need for greater transparency on process and methodologies, so as to enhance the understanding of what is driving dumping margins. This is needed independent of whether one believes that $\mathrm{AD}$ is a useful tool that helps governments undertake across-the-board liberalization or is a potential slippery slope. More detailed reporting by WTO Members on dumping-margin calculations in investigations to the WTO can be designed to address confidentiality concerns. For example, detailed data reported to the Secretariat could be kept confidential, but could be used to calculate and publish estimates of the impact certain types of methods have on average margins across a set of cases in a certain time period. 


\section{References}

Blonigen, Bruce A. and Chad P. Bown (2003), 'Antidumping and Retaliation Threats', Journal of International Economics, 60(2): 249-273.

Bown, Chad P. (2010), 'Taking Stock of Antidumping, Safeguards, and Countervailing Duties, 1990-2009', mimeo.

Bown, Chad P. and Rachel McCulloch (2010), 'Developing Countries, Dispute Settlement, and the Advisory Centre on WTO Law', World Bank Policy Research Working Paper No. 5168.

Bown, Chad P. and Thomas J. Prusa (2010), 'US Antidumping: Much Ado about Zeroing', World Bank Policy Research Working Paper No. 5352.

Bown, Chad P. and Alan O. Sykes (2008), 'The Zeroing Issue: A Critical Analysis of Softwood V', World Trade Review, 7(1): 121-142.

Egger, Peter and Douglas Nelson (2010), 'How Bad is Antidumping?: Evidence from Panel Data', The Review of Economics and Statistics, forthcoming.

Feinberg, Robert M. and Kara Marie Reynolds (2006), 'The Spread of Antidumping Regimes and the Role of Retaliation in Filings', Southern Economic Journal, 72(4): 877-890.

Finger, J. Michael and Julio J. Nogués (eds.) (2006), Safeguards and Antidumping in Latin American Trade Liberalization: Fighting Fire with Fire, Washington, DC: World Bank.

Grossman, Gene M. and Alan O. Sykes (2006), 'European Communities - Anti-Dumping Duties on Imports of Cotton-Type Bed Linen from India: Recourse to Article 21.5 of the DSU by India', World Trade Review, 5(1): 133-148.

Janow, Merit E. and Robert W. Staiger (2003), 'EC-Bed Linen European Communities - Anti-Dumping Duties on Imports of Cotton-Type Bed Linen from India', in Henrik Horn and Petros C. Mavroidis (eds.), The WTO Case Law of 2001, Cambridge: Cambridge University Press, pp. 115-139.

Nye, William W. (2009), 'The Implications of “Zeroing” for Enforcement of US Antidumping Laws', Journal of Economic Policy Reform, 12(4): 263-271.

Prusa, Thomas J. and Edwin Vermulst (2009), 'A One-Two Punch on Zeroing: US-Zeroing (EC) and US-Zeroing (Japan)', World Trade Review, 8(1): 187-241.

Vandenbussche, Hylke and Maurizio Zanardi (2010), 'The Chilling Trade Effects of Antidumping Proliferation', European Economic Review, 54(6): 760-777.

Viner, Jacob (1923), Dumping: A Problem in International Trade, Chicago: University of Chicago Press (reprinted in 1991 by Augustus M. Kelley, Fairfield, NJ). 